\title{
POTENTIAL POSSIBILITIES OF SOIL MESOFAUNA USAGE FOR BIODIAGNOSTICS OF SOIL CONTAMINATION BY HEAVY METALS
}

\author{
NADIIA YORKINA ${ }^{1}$, OLEXANDER ZHUKOV ${ }^{2}$, OLENA CHROMYSHEVA ${ }^{1}$
}

${ }^{1}$ Bogdan Khmelnitsky Melitopol State Pedagogical University, 20, Hetmanska Street, 72318, Melitopol Zaporizhzhya, Ukraine; e-mail: nadyayork777@gmail.com

${ }^{2}$ Department of Zoology and Ecology, Oles Honchar Dnipro National University, pr. Gagarina, 72, 49010, Dnipro, Ukraine; e-mail: zhukov_dnipro@ukr.net

\begin{abstract}
Yorkina N., Zhukov O., Chromysheva O.: Potential possibilities of soil mesofauna usage for biodiagnostics of soil contamination by heavy metals. Ekológia (Bratislava), Vol. 38, No. 1, p. 1-10, 2019.

The study of potential possibilities of mesofauna as bioindicator of soil contamination by heavy metals is one of the most important areas of urban ecology and soil biology. The work presents the results of ecotoxicological and bioindicative assessment of the environment and the biota of the Melitopol urbosystem of Ukraine. The dynamics of chemical properties of soils in different functional zones of the city is analysed. The complex indices of pollution of environmental components are determined. A bioindicative assessment of the ecological condition of the territory of the urbosystem on the indicators of vitality of the soil mesofauna is carried out. For the first time, regional species-bioindicators for the territory of the city of Melitopol were determined. The ecomorphic structure of soil mesofauna of various functional zones of the city was revealed.

Key words: heavy metals, biodiagnostics, soil mesofauna, urbosystem, ecotoxicological assessment.
\end{abstract}

\section{Introduction}

In urban areas, there is a degradation of edaphotops under the influence of anthropogenic pressure. Biodiagnostics is a tool that allows the timely detection of technogenically transformed areas of the city. As indicators of the state of anthropogenically disturbed soils of urbosystems, it is advisable to use complexes of mesopedobionts that specifically react to changes in environmental factors (humidity, temperature, chemical composition of soils, etc.) (Bardgett, 2002; Berger et al., 1993; Coleman, Crossley, 2004; Livesley et al., 2016; Paoletti, Hassall, 1999; Rebele, 1994).

In soil biodiagnostics, researchers study the structure, biodiversity and the state of the populations of soil animals, as well as the peculiarities of the ecological mechanisms of mesopedobionts response to the effects of pollutants (Dai et al., 2004; Didden, Rombke, 2001; Holmstrup, 2000; Kohler, 2002; Kunah, 2016; Paoletti, 1999).

Increasing the level of pollution causes the inhibition of saprophagous or activation of their vitality. A number of researchers attribute this process to the composition of pollutants 
that cause acidification or degradation of soils (Whitacre, 2013; Yorkina, 2016). Chemical contamination is reflected in the activity, quantity, diversity and age structure of mesopedobionts populations (Didden, Rombke, 2001; Holmstrup, 2000; Livesley et al., 2016; Zhukov, Shatalin, 2016). As a result of the presence of heavy metals in the soil, the number and diversity of mesopedobionts decreases, and the number of some species that fully occupy an ecological niche increases. As the susceptibility to heavy metal pollution increases, mesopedobionts rank in a row: woodlouse - mollusks and earthworms - spiders - polygons (Badtyev, 2007).

Thus, pollutants affect the reduction of the number, the biomass of invertebrates, cause depression of the saprophagous, increase the press of predators, change the spatial distribution and impoverishment of the species composition (Bardgett, 2002; Coleman, Crossley, 2004; Edwards, 1992; Engelmann, 1978; Wood, 2012).

The objective of the research was to study the groups of mesopedobionts in the context of biotopic features of soil contamination by heavy metals.

\section{Material and methods}

According to the research program, an ecotoxicological assessment and bio-diagnostics of Melitopol urbosystem were performed, and the ecological state of the city was established, in accordance with the structural and functional organization of the urbosystem (Table 1).

In the city of Melitopol there are the following types of soil: turf, mainly gleying sand, clay and sandy loam soils in combination with mild humus sands, Southern black humus and slightly argillaceous, dark brown saline soils. By mechanical composition there are sandy, clay and clay-sandy soils.

For ecological characteristics of soil of Melitopol urbosystem, the following set of parameters has been selected: the reaction of medium $(\mathrm{pH})$, the content of mobile forms of heavy metals with high biological activity - lead, cadmium, copper and zinc. Acidity was determined by a potentiometric method using a $\mathrm{pH}$ - meter of millivoltmeter pH-121 (ionomer EB 74). The content of moving forms of heavy metals was carried out by atomic absorption spec-

T a b l e 1. Location of functional areas of the city of Melitopol.

\begin{tabular}{|c|c|l|}
\hline № & Functional zone & \multicolumn{1}{c|}{ Name (functional purpose) } \\
\hline 1 & RZR & Area of the 'Refma' plant (industrial zone) \\
\hline 2 & CP & City Park (recreational area) \\
\hline 3 & MZTG & MZTG factory area (industrial zone) \\
\hline 4 & MD & Microdistrict (residential area) \\
\hline 5 & DPAM & District of plants 'Avtokoliorlyt' and MEMZ (industrial zone) \\
\hline 6 & IIG & Institute of Irrigated Gardening (recreation area) \\
\hline 7 & MHD & Melitopol hotel district (residential area) \\
\hline 8 & DNM & District of cottages in New Melitopol (residential area) \\
\hline 9 & KB & Kisiyarskaya beam (residential area) \\
\hline 10 & TC & Telecentre (transport area) \\
\hline 11 & SC & Southern crossing (transport, industrial zone) \\
\hline 12 & BB & Berdyansk bridge (transport area) \\
\hline 13 & PSH & Pishchane (residential area, highway area) \\
\hline 14 & FP & Forest Park (recreation area) \\
\hline 15 & AF & Airfield (residential area) \\
\hline
\end{tabular}


tral analysis using the VARIAN AA240FS spectrometer. Extraction of moving forms of heavy metals was carried out with ammonium acetate buffer solution at $\mathrm{pH} 4.8$.

Sampling of soil was carried out by the method of an envelope measuring $5 \times 5 \mathrm{~m}$ from a depth of $20-30 \mathrm{~cm}$. To characterize the ecotoxicological state of soils, the indicators of total pollution were calculated according to the formula (Dmitrenko, 2012):

$$
Z_{c}=\sum\left(\frac{C_{i}}{C_{\phi i}}+\ldots+\frac{C_{i}}{C_{\phi n}}\right)-(n-1),
$$

where $\mathrm{C}_{\mathrm{i}}$ is the concentration of heavy metals in the soil, $\mu \mathrm{g} / \mathrm{g}$; $\mathrm{Cf}_{\mathrm{i}}$ is the background value of this concentration, $\mu \mathrm{g} / \mathrm{g} ; \mathrm{n}$ - the number of total substances to be determined.

To estimate the level of soil contamination, an indicative scale of the risk of soil contamination is used (Table 2) (Dmitrenko, 2012).

T a b l e 2. Approximate scale of soil contamination risk.

\begin{tabular}{|l|c|}
\hline Category of soil pollution & Total pollution indicator $\mathbf{Z}_{\mathbf{C}}$ \\
\hline Acceptable & $<16$ \\
\hline Moderately dangerous & $16 \ldots . .32$ \\
\hline Dangerous & $32 \ldots 128$ \\
\hline Extremely dangerous & $>128$ \\
\hline
\end{tabular}

T a b l e 3. Criteria for assessing the quality of soils in the state of mesopedobionts (according to Batdiyev, 2007).

\begin{tabular}{|l|c|c|c|c|c|}
\hline \multirow{2}{*}{$\begin{array}{l}\text { Decrease of vitality with } \\
\text { respect to norm }\end{array}$} & \multicolumn{5}{|c|}{ Criteria of the ecological state of water objects } \\
\cline { 2 - 6 } & $\begin{array}{c}\text { favorable } \\
\text { ES }\end{array}$ & $\begin{array}{c}\text { tense } \\
\text { ES }\end{array}$ & $\begin{array}{c}\text { critical } \\
\text { ES }\end{array}$ & $\begin{array}{c}\text { crisis } \\
\text { ES }\end{array}$ & $\begin{array}{c}\text { catastrophic } \\
\text { ES }\end{array}$ \\
\hline $\mathrm{G}_{\mathrm{i}} \%$ & less than 11 & $11-25$ & $26-50$ & $51-80$ & more than 80 \\
\hline
\end{tabular}

Note: ES - ecological situation.

The degree of soil contamination was determined by the index of vitality of invertebrates. To do this, depending on the sensitivity to soil contamination by moving forms of heavy metals, the representatives of the soil mesofauna were divided into groups, each of which was assigned the weighting coefficients (Badtyev, 2007):

- Isopoda live in relatively clean soil $\left(\mathrm{W}_{\mathrm{i}}=1\right)$,

- Mollusca (Gastropoda), Lumbricina live in a moderately contaminated soil $\left(\mathrm{W}_{\mathrm{m}, \mathrm{l}}=0.8\right)$,

- $\quad$ the presence of Aranei indicates weakly contaminated soil $\left(\mathrm{W}_{\mathrm{a}}=0.6\right)$,

- $\quad$ while the representatives of the superclass Myriapoda adapt in soils with an average level of pollution $\left(\mathrm{W}_{\mathrm{m}}=0.4\right)$.

The method of soil quality bioindication is based on the comparison of the index of vitality of soil invertebrates in the studied and control sites. To do this, the sites of bioindication by size $5 \times 5 \mathrm{~m}$ were made. On each of them, $5 \mathrm{soil}$ trenches were made using an envelope method with the help of a sapper blade. The size of the trench was $25 \times 25 \mathrm{~cm}$, depth of $30 \mathrm{~cm}$. The soil of the trench was placed on a transparent film and carefully split. The found animals were placed in transparent packages with the help of the tweezers. Then, the data of bioindication in the studied area $\mathrm{G}_{\mathrm{bi}}$ were compared with the data of bioindication in the control section $G_{b c}$ by the formula (Badtyev, 2007):

$$
\Delta \mathrm{G}_{6}=\left(\mathrm{G}_{6 \mathrm{c}}-\mathrm{G}_{6 \mathrm{i}}\right) / \mathrm{G} 6 \mathrm{c} \times 100 \% .
$$

The ecological status of the soil was evaluated according to the criteria in Table 3 . The calculations and graphic design of the data obtained in the work were carried out using the Microsoft Excel program and the software package 'STATISTICA - 6.0'. 


\section{Results and discussion}

As the degree of soil contamination bioindicators, we used mesopedobionts - the representatives of the Diplopoda and Chilopoda classes, Aranei and Isopoda series, Trachelipodidae, Armadillidiidae, Lumbricidae, Enidae, Limacidae, Hygromiidae, Helicidae and Bradybaenidae families (Stoev, 2002).

In Melitopol, the most alkaline soils are in the area of industrial facilities (plant 'Refma' $(\mathrm{pH}=7.68 \pm 0.40)$, MZTG factory $(\mathrm{pH}=7.69 \pm 0.34)$, Avtokoliorlyt and MeMZ plants $(\mathrm{pH}$ $=7.56 \pm 0.40$ ), transport highways (South crossing $\mathrm{pH}=7.70 \pm 0.37)$, Berdyansk bridge $(\mathrm{pH}$ $=7.97 \pm 0.42)$, Telecentre $(\mathrm{pH}=7.47 \pm 0.41)$ and residential areas (Pishchane $(\mathrm{pH}=7.43$ $\pm 0.38)$, Kiziyarskaya beam $(\mathrm{pH}=7.68 \pm 0.33)$, the district of Melitopol hotel $(\mathrm{pH}=7.59 \pm$ $0.34)$.

The results of ecotoxicological assessment of the state of Melitopol urbosystem testify that the background content (FP) of lead amounted to 0.3 MAC, zinc - 0.2 MAC, copper - 0.35 MAC, while cadmium in reference sites is present in small amounts (0.02 MAC).

Ecotoxicological assessment of the spatial distribution of movable forms of heavy metals in the city shows that their distribution is uneven. Elements with spatially coordinated behaviour $(\mathrm{Pb}, \mathrm{Cu}$ and $\mathrm{Zn}$ ) form areas of pollution in the form of stable associations around their sources. These associations are most characteristic of emissions of certain industries (for example, in areas adjacent to major companies of the city, $\mathrm{Pb}$ concentration consistently exceeds MAC by 1.5-2 times, and zinc - 4 times. They are in the areas of highways. Moving forms of cadmium are found in the functional areas of industrial facilities (MZTG factory, 'Avtokoliorlyt', MeMZ and 'Refma' plants) exceeding MAC by 1.5 times. The excess of background values set by the content of $\mathrm{Pb}$ was found in all soil samples of Melitopol urbosystem. The general linear model allowed to establish that the factors of the season, the type of zone and $\mathrm{pH}$ determined $94 \%$ of the variability of the content of movable forms of lead (Table 4). A statistically significant predictor of lead is the year. Throughout the period of studies, the content of movable forms of lead naturally increased. Seasonal features were also found to be important in the dynamics of this heavy metal: in spring, its content is regularly lower than in autumn, which can be linked to the dynamics of precipitation in the steppe zone of Ukraine. Probably, in winter there is a flushing of lead from the soil profile. Also, this feature can be explained by the biotic factor, the effect of which is accumulated during the vegetation season. The general linear model indicates a lack of statistically significant influence of soil $\mathrm{pH}$ on the content of movable forms of lead ( $\mathrm{p}=0.22$ ). But it should be noted that direct comparison of $\mathrm{pH}$ and content of movable forms of lead allows to obtain a strong correlation between these parameters $(\mathrm{r}=0.60, \mathrm{p}=0.00)$.

Obviously, this connection is not functional, but due to the influence of general factors, both on the $\mathrm{pH}$ variation, and on the variation of the content of moving forms of lead in the soil. The variation of lead content due to the zone type is statistically significant (Table 8).

The highest indicators of lead were recorded along the transport highways (Southern crossing and Berdyansk bridge - 2.7 MAC), production facilities ('Avtokoliorlyt' and MeMZ plants - 2 MAC, 'Refma' plant - 2.1 MAC, MZTG factory - 1.8 MAC) and residential areas (Microdistrict - 2 MAC, Kisiyarskaya beam - 2.1 MAC). The lowest indicator is on the ter- 
$\mathrm{T} \mathrm{a} \mathrm{b} \mathrm{l} \mathrm{e} \mathrm{4.} \mathrm{Total} \mathrm{linear} \mathrm{model} \mathrm{of} \mathrm{the} \mathrm{influence} \mathrm{of} \mathrm{the} \mathrm{year,} \mathrm{season,} \mathrm{zone} \mathrm{type} \mathrm{and} \mathrm{pH}$ content of moving lead in the soil $(\mathrm{R} 2=0.94)$.

\begin{tabular}{|c|c|c|c|c|c|}
\hline Parameter & $\begin{array}{c}\text { Sum of } \\
\text { squares }\end{array}$ & $\begin{array}{c}\text { Degrees } \\
\text { of freedom }\end{array}$ & $\begin{array}{c}\text { The average } \\
\text { amount of } \\
\text { squares }\end{array}$ & F-reference & $\boldsymbol{p}$-level \\
\hline Constant & 2522.55 & 1 & 2522.55 & 143.24 & 0.00 \\
\hline $\mathrm{pH}$ & 26.55 & 1 & 26.55 & 1.51 & 0.22 \\
\hline Year & 917.01 & 4 & 229.25 & 13.02 & 0.00 \\
\hline Season & 105.81 & 1 & 105.81 & 6.01 & 0.01 \\
\hline Zone & 75700.48 & 14 & 5407.18 & 307.03 & 0.00 \\
\hline Error & 7555.20 & 429 & 17.61 & - & - \\
\hline
\end{tabular}

$\mathrm{T}$ a b l e 5. The general linear model of influence of year, season, zone type and $\mathrm{pH}$ content of moving zinc in the soil $(\mathrm{R} 2=0.97)$.

\begin{tabular}{|c|c|c|c|c|c|}
\hline Parameter & $\begin{array}{c}\text { Sum of } \\
\text { squares }\end{array}$ & $\begin{array}{c}\text { Degrees of } \\
\text { freedom }\end{array}$ & $\begin{array}{c}\text { The average } \\
\text { amount of } \\
\text { squares }\end{array}$ & F-reference & $\boldsymbol{p}$-level \\
\hline Constant & 2094.57 & 1 & 2094.57 & 111.04 & 0.00 \\
\hline $\mathrm{pH}$ & 27.99 & 1 & 27.99 & 1.48 & 0.22 \\
\hline Year & 602.11 & 4 & 150.53 & 7.98 & 0.00 \\
\hline Season & 151.01 & 1 & 151.01 & 8.01 & 0.00 \\
\hline Zone & 185903.32 & 14 & 13278.81 & 703.97 & 0.00 \\
\hline Error & 8092.11 & 429 & 18.86 & - & - \\
\hline
\end{tabular}

$\mathrm{T}$ a b l e 6 . The general linear model of influence of year, season, zone type and $\mathrm{pH}$ content of moving copper in the soil $(\mathrm{R} 2=0.95)$.

\begin{tabular}{|c|c|c|c|c|c|}
\hline Parameter & $\begin{array}{c}\text { Sum of } \\
\text { squares }\end{array}$ & $\begin{array}{c}\text { Degrees of } \\
\text { freedom }\end{array}$ & $\begin{array}{c}\text { The average } \\
\text { amount of } \\
\text { squares }\end{array}$ & F-reference & $\boldsymbol{p}$-level \\
\hline Constant & 583.47 & 1 & 583.47 & 152.17 & 0.00 \\
\hline $\mathrm{pH}$ & 8.61 & 1 & 8.61 & 2.25 & 0.13 \\
\hline Year & 7.20 & 4 & 1.80 & 0.47 & 0.76 \\
\hline Season & 38.35 & 1 & 38.35 & 10.00 & 0.00 \\
\hline Zone & 27563.25 & 14 & 1968.80 & 513.48 & 0.00 \\
\hline Error & 1644.90 & 429 & 3.83 & - & - \\
\hline
\end{tabular}

ritory of the City Park, which was at the level of the background value. The tendency to increase the content of lead in the surface layer of soil is also noted in the area of residential areas. Increasing in the concentration of lead in samples from the territory of a number of industrial enterprises is not significant.

The variability of the content of movable forms of zinc by $97 \%$ is determined by such factors as year, season, zone type and $\mathrm{pH}$ (Table 5). 
$\mathrm{T} \mathrm{a} \mathrm{b} \mathrm{l} \mathrm{e} \mathrm{7.} \mathrm{The} \mathrm{general} \mathrm{linear} \mathrm{model} \mathrm{of} \mathrm{influence} \mathrm{of} \mathrm{year,} \mathrm{season,} \mathrm{zone} \mathrm{type} \mathrm{and} \mathrm{pH}$ content of movable cadmium in the soil $(\mathrm{R} 2=0.95)$.

\begin{tabular}{|c|c|c|c|c|c|}
\hline Parameter & $\begin{array}{c}\text { Sum of } \\
\text { squares }\end{array}$ & $\begin{array}{c}\text { Degrees of } \\
\text { freedom }\end{array}$ & $\begin{array}{c}\text { The average } \\
\text { amount of } \\
\text { squares }\end{array}$ & F-reference & p-level \\
\hline Constant & 1.21 & 1 & 1.21 & 72.65 & 0.00 \\
\hline $\mathrm{pH}$ & 0.03 & 1 & 0.03 & 1.81 & 0.18 \\
\hline Year & 0.24 & 4 & 0.06 & 3.67 & 0.01 \\
\hline Season & 0.06 & 1 & 0.06 & 3.72 & 0.05 \\
\hline Zone & 120.30 & 14 & 8.59 & 516.57 & 0.00 \\
\hline Error & 7.14 & 429 & 0.02 & - & - \\
\hline
\end{tabular}

T a ble 8 . The content of moving forms of heavy metals in the soils of the functional zones of the city of Melitopol $(\mu \mathrm{g} / \mathrm{g})$.

\begin{tabular}{|l|c|c|c|c|c|c|}
\hline $\begin{array}{l}\text { Functional } \\
\text { zone }\end{array}$ & $\mathbf{P b}^{2+}$ & $\mathbf{Z} \mathbf{n}^{2+}$ & $\mathbf{C u}^{2+}$ & $\mathbf{C d}^{2+}$ & $\begin{array}{c}\text { Total indicator of } \\
\text { soil contamination } \\
\text { level, } \mathbf{Z} \mathbf{c}\end{array}$ & $\begin{array}{c}\text { Category of soil } \\
\text { contamination }\end{array}$ \\
\hline RZR & $39.58 \pm 1.83$ & $71.56 \pm 4,37$ & $35.62 \pm 1.43$ & $1.55 \pm 0.067$ & $122.90 \pm 3.28$ & Dangerous \\
\hline KB & $41.74 \pm 1.88$ & $55.78 \pm 3.28$ & $15.54 \pm 0.89$ & $0.26 \pm 0.007$ & $45.69 \pm 0.84$ & Dangerous \\
\hline MZTG & $36.86 \pm 2.2$ & $60.78 \pm 2.25$ & $13.5 \pm 0.78$ & $1.52 \pm 0.048$ & $101.95 \pm 3.32$ & Dangerous \\
\hline MD & $48.01 \pm 2.63$ & $14.19 \pm 0.75$ & $2.4 \pm 0.16$ & $0.06 \pm 0.002$ & $16.07 \pm 0.33$ & Acceptable \\
\hline DPAM & $42.79 \pm 2.28$ & $26.94 \pm 1.65$ & $21.84 \pm 0.43$ & $1.78 \pm 0.08$ & $107.81 \pm 2.65$ & Dangerous \\
\hline IIG & $8.38 \pm 0.47$ & $6.29 \pm 0.38$ & $12.05 \pm 0.59$ & $0.06 \pm 0.003$ & $12.75 \pm 0.22$ & Acceptable \\
\hline CP & $5.52 \pm 0.29$ & $6.42 \pm 0.25$ & $2.61 \pm 0.11$ & $0.06 \pm 0.002$ & $3.68 \pm 0.08$ & Acceptable \\
\hline MHD & $14.78 \pm 0.86$ & $8.04 \pm 0.44$ & $5.5 \pm 0.34$ & $0.05 \pm 0.004$ & $8.48 \pm 0.23$ & Acceptable \\
\hline DNM & $7.66 \pm 0.45$ & $12.71 \pm 0.52$ & $1.47 \pm 0.08$ & $0.06 \pm 0.002$ & $6.29 \pm 0.38$ & Acceptable \\
\hline TC & $22.25 \pm 1.44$ & $13.95 \pm 0.64$ & $3.01 \pm 0.15$ & $0.12 \pm 0.008$ & $15.92 \pm 0.30$ & Acceptable \\
\hline SC & $40.32 \pm 1.72$ & $14.06 \pm 0.81$ & $12.49 \pm 0.55$ & $0.26 \pm 0.011$ & $31.46 \pm 0.68$ & Moderately dangerous \\
\hline BB & $53.72 \pm 2.84$ & $60.55 \pm 4.05$ & $13.13 \pm 0.65$ & $0.72 \pm 0.050$ & $70.28 \pm 1.07$ & Dangerous \\
\hline PSH & $9.77 \pm 0.41$ & $7.81 \pm 0.42$ & $12.29 \pm 0.68$ & $0.40 \pm 0.023$ & $32.07 \pm 0.86$ & Moderately dangerous \\
\hline AF & $25.97 \pm 1.15$ & $7.83 \pm 0.34$ & $2.8 \pm 0.14$ & $0.07 \pm 0.005$ & $10.14 \pm 0.20$ & Acceptable \\
\hline FP & $5.17 \pm 0.15$ & $4.56 \pm 0.23$ & $1.03 \pm 0.04$ & $0.01 \pm 0.001$ & $1.97 \pm 0.56$ & Acceptable \\
\hline
\end{tabular}

In the seasonal aspect, there is a natural tendency to increase the content of movable forms of zinc in autumn compared with the spring period. The influence of $\mathrm{pH}$ on the content of moving forms is not statistically significant, but direct comparison gives a statistically significant correlation $(r=0.49, \mathrm{p}=0.00)$. For the annual dynamics, a statistically significant trend is established. Throughout the period, the content of moving forms of zinc increases. An analysis of the content of moving zinc forms in Melitopol soils showed their significant excess in edaphotops of the functional zones of industrial objects ('Refma' plant - 3.2 MAC, MZTG factory - 2.6 MAC), residential areas (Kisiyarskaya beam - 2.5 MAC) and highways (Berdyansk bridge - 2.7 MAC) (Table 8).

The smallest amount of zinc was noted in the recreational destinations (City Park and Institute of Irrigated Gardening), but the indicator slightly exceeded the background value by 1.2 and 1.3 times, respectively. 
The general linear model explains $95 \%$ of the variability of the content of moving copper forms in the soil of the city (Table 6).

Statistically probable predictors are the season and the type of functional zone. During the years, the statistically probable trends of change in the content of moving copper forms have not been established. In spring, the content of mobile forms of copper is statistically less than in autumn. Acidity of soils also did not show statistically significant influence within the framework of the model, but a direct correlation is obtained with a high correlation coefficient of $\mathrm{pH}$ and moving forms of copper $(\mathrm{r}=0.41, \mathrm{p}=0.00)$. Of course, the general factors may explain the correlation between these soil properties.

The content of copper exceeds the maximum MAC in the area of industrial facilities ('Refma' plant - 11.4 MAC, 'Avtokoliorlyt' and MeMZ plants - 7 MAC, MZTG factory - 4.6 MAC), residential areas (Kisiyarskaya beam, Peshchany - 4.8 MAC), highways (Southern crossing - 4.8 MAC, Berdyansk bridge - 4.5 MAC), recreational areas (Institute of Irrigated Gardening - 4.0 MAC). At the same time, in certain functional zones, the concentration of copper did not exceed MAC (CP, MD, DNM) (Table 8).

The general linear model explains $95 \%$ of the content variability in the soil of moving cadmium, using factors such as year, season, zone type and $\mathrm{pH}$ (Table 7). The acidity of the soil is not statistically significant as a predictor of the content of moving cadmium, although these indicators are characterized by a statistically significant correlation $(r=0.42, p=0.00)$. In the seasonal aspect, the content of moving cadmium in spring is regularly lower than in autumn.

The ecotoxicological assessment made it possible to establish that after 2009 there was a sharp decrease in cadmium content in the soils of Melitopol, after which there was a steady tendency to increase this indicator.

The analysis of the content of moving cadmium forms in soils showed their excess in comparison with the background indicators. The largest concentrations were observed in the zones of industrial objects (the region of 'Refma' plant, MZTG factory, 'Avtokoliorlyt' and MeMZ plants), the smallest concentrations - in the zones of recreational territories (IIG, $\mathrm{CP})$ and residential areas (MHD, DNM), but here they were 2-3 times higher than the background level (Table 8).

By reducing the total pollution index $Z_{c}$, the studied functional zones made the following list: region of the 'Refma' plant $\rightarrow$ the area of the plants 'Avtokoliorlyt' and MeMZ $\rightarrow$ the area of the MZTG factory $\rightarrow$ Berdyansk bridge $\rightarrow$ Kiziyarskaya beam $\rightarrow$ Pishchanaya $\rightarrow$ Southern crossing $\rightarrow$ Institute of irrigated gardening $\rightarrow$ Microdistrict $\rightarrow$ Telecentre $\rightarrow$ Airfield $\rightarrow$ Location of Hotel Melitopol $\rightarrow$ District of cottages in New Melitopol $\rightarrow$ City Park (Table 8).

The decrease in the vitality of mesopedobionts depends on the total indicator of soil contamination level (Fig. 1).

Analytically, this dependence can be expressed by the following equation:

$$
\overline{\mathrm{G}}_{\mathrm{m}}=1.72-58.16 * \log _{10} \mathrm{Z}_{\mathrm{c}} .
$$

The conducted studies allowed to carry out an ecotoxicological assessment of the ecological state of the soil in Melitopol and to compare the results with the data of the biodiagnostic research. 


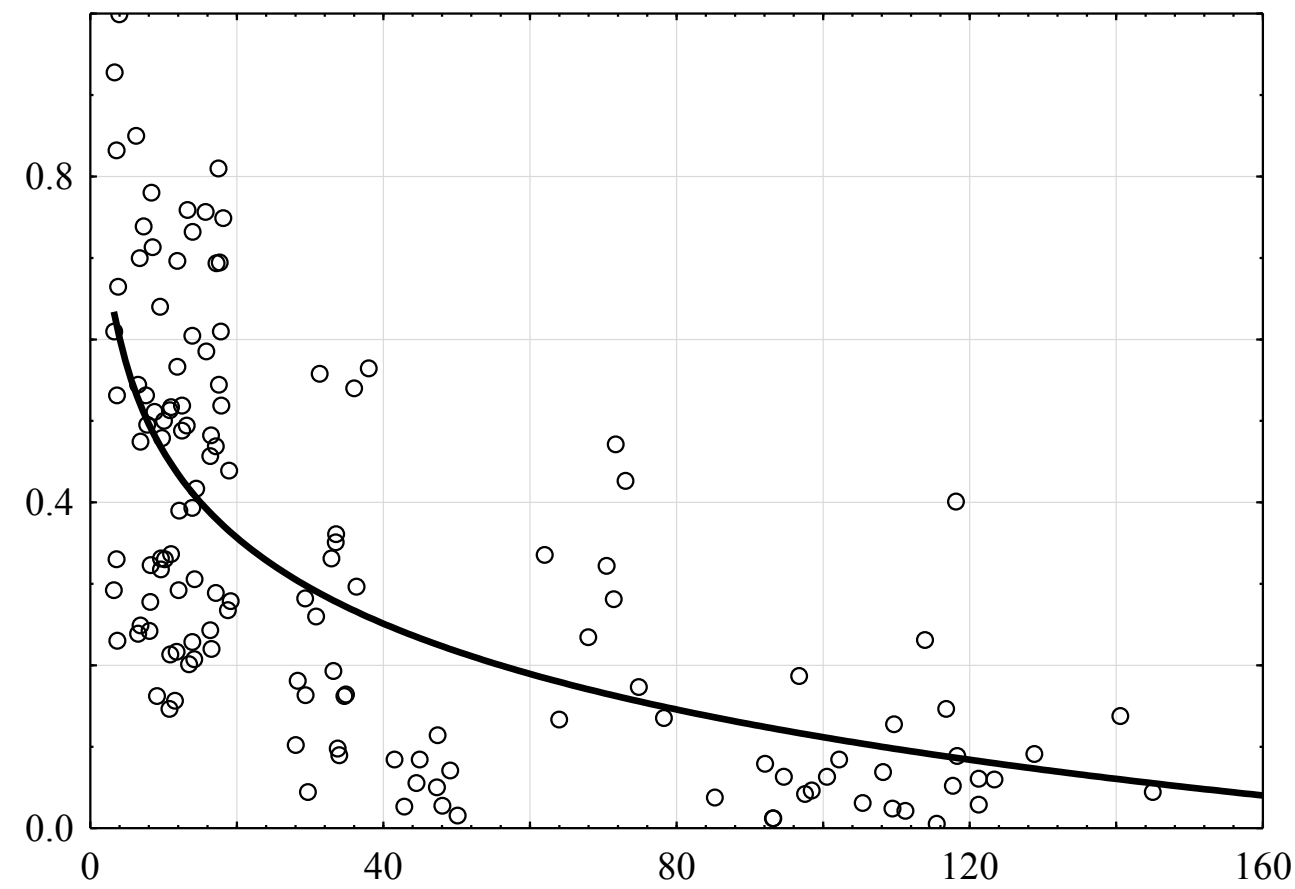

Fig. 1. Dependence of the decrease in the vitality of mesopedobionts from the total indicator of soil contamination level.

The high alkalinity of the soils of Melitopol urbosystem is due to the arrival of suspended particles from the highways (Ca and Mg carbonates), as well as dust. According to Dmitrenko (2016), in alkaline medium, $\mathrm{Cu}, \mathrm{Zn}, \mathrm{Cd}$ have weak mobility, and $\mathrm{Pb}$ is practically immobile. In the functional zones where the alkaline soils predominate, the zones of anomalies of chalcopylic elements are recorded (Kalabekov, 2003).

Sverlova N. (2004) indicate that in alkaline soils, a predominance of calcefils - stomach molluscs - has been noted, which allows them to be used to indicate the level of alkalization of soils. Berger and Dallinger (1993) believe that ground-based mugs are effective indicators of contamination of edaphotops by heavy metals.

According to the vitality of the mesophane groups (Batdyev, 2007), the quality of the soil of the urbosystem is evaluated. Thus, the ecological state of the functional zones can be recognized as favourable for 1 functional zone (6.7\%), stress - for 4 functional areas (26.7\%), critical - for 3 functional areas (20.0\%), crisis - for 3 functional areas (20.0\%) and catastrophic - for 4 functional zones $(26.7 \%)$. The obtained data indicate that the total soil pollution index of the 8 functional zones of the city (53.3\%) are classified as admissible level of pollution, 2 - as moderately dangerous level (13.3\%), 5 - as dangerous level (33.34\%). 
It should be noted that the total indicator of soil contamination is based on the assumed non-toxicity of the toxic influence of heavy metals, which is a rather general idea. Indeed, there is, of course, synergism and antagonism of the influence of heavy metals on the grouping of soil invertebrates (Dai et al., 2004; Kohler, 2002; Kunah , 2016; Mohammadein et al., 2013).

The dependence of the decrease of the mesopedobionts' vitality index on the total indicator of soil contamination level indicates the presence of the stability in the groups of soil invertebrates. With increased level of pollution, the decrease in the vitality of mesopedobionts is inhibited, which can be explained by the activation of homeostatic mechanisms in the group (Zhukov, Shatalin, 2016; Zadorozhnaya, 2018).

Some authors emphasize (Kohler, 2002; McKinney, 2006) that in anthropogenically altered areas, the population of zoophages increases, there is homogenization of the cenomorphic composition of the main groups of mesopedobionts with the dominance of certain species.

\section{Conclusion}

As a result of the ecotoxicological and biodiagnostic assessment of the soil condition of Melitopol urbosystem, it was found that:

- For lead and zinc, there is a steady and statistically significant tendency to increase their content. During the years, the statistically probable trends of change in the content of moving copper forms have not been established. After 2009, there was a sharp decrease in the cadmium content in soils, after which there was a steady tendency to increase this index.

- In spring, the content of lead, zinc, copper and cadmium is lower than in autumn. The main source of soil contamination of the urbosystem by lead is vehicles.

- On the basis of the complex of bioindicative researches, which foresee the determination of the indicators of the vitality of the soil mesophane, an ecological state of edaphotops of the urbosystem of Melitopol was conducted.

- It has been proved that in anthropogenically altered areas, the population of zoophages increases, homogenization of the cenomorphic composition of the main groups of mesopedobionts with the dominance of certain species is observed. In alkaline soils, the predominance of calcefils - polygons, woodlice, stomach molluscs - has been noted, which allows them to be used to indicate the level of alkalization of soils.

\section{References}

Badtyev, Yu.S. (2007). Methodology of the bio-diagnostics of the quality of the environment of military facilities. Moscow: The Moscow State University it. M.V. Lomonosov.

Bardgett, R.D. (2002). Causes and consequences of biological diversity in soil. Zoology, 105, 367-374. DOI: 10.1078/0944-2006-00072.

Berger, B., Dallinger, R., Felder, E. \& Moser J. (1993). Budgeting the flow of zinc through the terrestrial gastropod Helix pomatia (L.). In Ecotoxicology of metals in invertebrates (pp. 291-313). Chelsea: Lewis Publishers.

Berger, B. \& Dallinger R. (1993). Terrestrial snails as quantitative indicators of environmental metal pollution. Environ. Monit. Assess., 25(1), 65-84. DOI: 10.1007/BF00549793.

Cobbett, C. \& Goldsbrough P. (2002). Phytochelatins and metallothioneins: roles in heavy metal detoxification and homeostasis. Annual Review of Plant Biology, 53, 159-182. DOI: 10.1146/annurev.arplant.53.100301.135154. 
Coleman, D.C. \& Crossley D.A. (2004). Fundamentals of soil ecology. Academic Press.

Dai, J., Becquerb, T., Rouillerc, J.H., Reversata, G., Bernhard-Reversata, F., Nahmania, J. \& Lavelle P. (2004). Heavy metal accumulation by two earthworm species and its relationship to total and DTPA-extractable metals in soils. Soil Biol. Biochem., 36, 91-98. DOI: 10.1016/j.soilbio.2003.09.001.

Didden, W. \& Rombke J. (2001). Enchytraeids as indicator organisms for chemical stress in terrestrial ecosystems. Ecotoxicol. Environ. Saf., 50, 25-43. DOI: 10.1006/eesa.2001.2075.

Dmitrenko, V.P. (2012). Ecological monitoring of the technosphere: textbook. St. Petersburg: Lan.

Edwards, C.A. (1992). Ecotoxicology of earthworms. Andover: Intercept.

Engelmann, H.-D. (1978). Zur Dominanzklassifizierung von Bodenartropoden. Pedobiologia, 18(5/6), 378-380.

Holmstrup, M. (2000). Field assessment of toxic effects of reproduction in the earthworms Aporrectodea longa and A. rosea. Environ. Toxicol. Chem., 19(7), 1781-1787. DOI: 10.1002/etc.5620190711.

Kalabekov, A.L. (2003). Structural and functional organization and ecological monitoring of urban megacity. Abstract of thesis. Moscow: Moscow State University M.V. Lomonosov.

Kohler, H-R. (2002). Localization of metals in cells of saprophagous soil arthropods (Isopoda, Diplopoda, Collembola). Microscopy Research and Technique, 56(5), 393-401. DOI: 10.1002/jemt.10039.

Kunah, O.N. (2016). Functional and spatial structure of the urbotechnozem mesopedobiont community. Visnyk of Dnipropetrovsk University, Biology, Ecology, 24(2), 473-483.

Livesley, S.J., McPherson, E.G. \& Calfapietra C. (2016). The urban forest and ecosystem services: Impacts on urban water, heat and pollution cycles at the tree, street and city scale. J. Environ. Qual., 45, 119-124. DOI: 10.2134/ jeq2015.11.0567.

McKinney, M.L. (2006). Urbanization as a major cause of biotic homogenization. Biol. Conserv., 127, 247-260. DOI: 10.1016/j.biocon.2005.09.005.

Mohammadein, A., EL-Shenawy, N.S. \& AL-Fahmie Z.H.H. (2013). Bioaccumulation and histopathological changes of the digestive gland of the land snail Eobania vermiculata (Mollusca: Gastropoda), as biomarkers of terrestrial heavy metal pollution in Taif city. Italian Journal of Zoology, 80(3), 345-357. DOI: 10.1080/11250003.2013.804957.

Paoletti, M.G. (1999). Invertebrate biodiversity as indicators of sustainable landscapes - practical use of invertebrates to assess sustainable land-use. Amsterdam: Elsevier.

Paoletti, M.G. \& Hassall M. (1999). Woodlice (Isopoda: Oniscidea): their potential for assessing sustainability and use as bioindicators. Agric. Ecosyst. Environ., 74, 157-165. DOI: 10.1016/S0167-8809(99)00035-3.

Rebele, F. (1994). Urban ecology and special features of urban ecosystems. Global Ecology and Biogeographiy Letters, 4, 173-187.

Sverlova, N. (2004). Landschnecken-Farbpolymorphismus aus physikalischen Gründen (Gastropoda: Pulmonata: Stylommatophora). Malakol. Abh. (Dresd.), 22, 131-145.

Stoev, P.A. (2002) Catalogue and key to the centipedes (Chilopoda) of Bulgaria. Sofia, Moscow.

Whitacre, D.M. (2013). Reviews of environmental contamination and toxicology. New York: Springer Science+Business Media. DOI: 10.1007/978-1-4614-6470-9.

Wood, M. (2012). Soil biology. US: Springer.

Yorkina, N.V. (2016). Impact of technogenic pollution of urban environment on vitality indicators of urban biota (Mollusk fauna, soil mesofauna, epiphytic lichens). Moscow University Biological Sciences Bulletin, 71(3), 177-183.

Zadorozhnaya, G.A. (2018). Spatiotemporal dynamics of soil penetration resistance of recultivated soil. Ekológia (Bratislava), 37(1), 82-89. DOI: 10.2478/eko-2018-0008.

Zhukov, A.V. \& Shatalin D.B. (2016). Hygrotope and trophotope of the steppe pridniprovie biogeocenosis as determinants of the earthworms (Lumbricidae) communities $\beta$-diversity. Biological Bulletin of Bogdan Chmelnitsky Melitopol State Pedagogical University, 6(2), 129-157.

Zhukov, A. \& Zadorozhnaya G. (2016). Spatial heterogeneity of mechanical impedance of atypical chernozem: the ecological approach. Ekológia (Bratislava), 35(3), 263-278. DOI: 10.1515/eko-2016-0021. 